\title{
TFG/NTRK1 Fusion Gene
}

National Cancer Institute

\section{Source}

National Cancer Institute. TFG/NTRK1 Fusion Gene. NCI Thesaurus. Code C99571.

A fusion gene $(\sim 2 \mathrm{~kb})$ that results from a chromosomal translocation $\mathrm{t}(1 ; 3)(\mathrm{q} 21 ; \mathrm{q} 11)$ that fuses the 5 ' half of the TFG gene to the 3' portion of the NTRK1 gene. This rearrangement is associated with papillary thyroid carcinoma. 